\title{
Implementation of Fuzzy Logic Controller in Solar PV Array Based AC Drives
}

\author{
Arunesh Kumar Singh, Abhinav Saxena
}

\begin{abstract}
This paper shows the real implementation of fuzzy logic controller in an AC drive system (Induction motor Drive) under Solar PV array-based system. The switching of boost converter is controlled with help of fuzzy logic by taking inputs from solar PV array while For Inverter switching is done by using fuzzy logic controller by taking inputs from induction motor drive. Initially, $20 \mathrm{~kW}$ solar PV array is designed for feeding the $10 \mathrm{Kw}$ Induction motor drive with the help MATLAB/SIMULINK. The complete system gives reliable, smooth, efficient, lesser harmonic content level in the output.
\end{abstract}

Index Terms: solar PV array, fuzzy, Induction motor, switching.

\section{INTRODUCTION}

At present, prime challenge for researchers is efficient generation of green energy. More usage of fossil fuels like gas, coal and oil produces green house effect as wells pollutes the environment[1]. As population is increasing so is the global energy demand also increasing thereby depleting the conventional energy resources and increase in cost of fossil fuel. So, there is need to explore renewable source of energy for sustainable development. Among different renewable sources of energy solar energy is of extremely important as sun exhibit 384.6 yotta watts of energy in the form of light and radiations[2]. Currently India has $26 \mathrm{GW}$ solar installed capacity as on 30 September 2018. India has

expanded solar-generation capacity to 8 times from 2,650 MW as on 26 May 2014 to about 20 GW as on 31 January 2018. Solar powered pumps are operated by an AC drive where an inverter is used with an AC motor. Induction motor has it's forte in size, ruggedness, and efficiency. DC output of solar PV array is increased by boost converter and the output of boost converter is fed into an inverter which further gives $\mathrm{AC}$ output[3]. Further the output from inverter is given to motor which drives the motor. Disadvantage of this method is that the output power of solar modules are of very low efficiency because of non linear radiation of Sun. So to optimize solar module output in order to have stable power, fuzzy logic module for Maximum Power Point Tracking (MPPT) is implemented in order to improve the performances of the system. The system designed here is proposed in order to optimize the photovoltaic voltage of solar module and supply of voltage source inverter so as to change the performance of induction motor and this is done by the help of Fuzzy logic controller[4].Photovoltaic system converts sunlight into electricity. Power electronic converters are used in order to extract the electricity from PV devices. These type of converters can be used to regulate voltage and current at the load end in order to control the flow of power in grid-connected system, and for tracking point of maximum power of the device. Basically PV cell is a p-n junction semiconductor diode[5],[6],[7]. Solar panels used now a days are mostly called as PV modules. One photovoltaic(PV) module is made of multiple interconnected cells. Difference between solar cells and PV modules is that PV modules are evenly sized and packed in weather resistant housing for easy installation. Study and application of photovoltaic devices is known as photovoltaics[8],[9],[10],[11]. Induction motor has wide variety of applications with more than $85 \%$ application in industries. For domestic purpose single phase induction motor has high applicability. It is mainly used for constant speed operations because speed drop from no-load to full load is very less. Therefore, earlier induction motor was used primarily for constant speed applications. Earlier the methods used for speed control were highly inefficient. So, earlier dc motor were used more but dc motor has commutator and brushes which require regular maintenance thereby making dc motor improper for usage. So, nowadays induction motor are highly used as it is simple, rugged and cheaper machinery. Squirrel cage type motor is used more. They are designed for fans, blower, cranes. conveyors etc[12],[13],[14].

\section{FUZZY LOGIC CONTROLLER}

Solar panel specifications are considered to increase the power of solar module and these specifications are used as inputs variables of fuzzy logic algorithm. Inputs to a Fuzzy Logic Controller are being processed by using linguistic variables which are defined by membership functions. Membership functions are so chosen such that they cover entire universe content. In order to avoid discontinuity in respect with minor changes at input level, the adjacent fuzzy sets must overlap with each other. Methods which are used for fuzzy inference technique most commonly is Mamdani method which is performed in the following three steps: fuzzification, defuzzification and inference mechanism. The second step of Mamdani method i.e. interference mechanism uses fuzzy rules for linguistic variables. The linguistic variables are categories as Negative Big (NB), Negative Small (NS), Negative medium (NM), High Big(HB), High medium(HM),High low(HL) and High small(HS) in every fuzzy set that are created. The inputs i.e. Voltage Error (Verror) and Change of Voltage Error (VCOE) are imposed to control the output variable of Duty ratio (D). 


\section{MATHEMATICAL MODELLING OF INDUCTION MOTOR}

The system consists of PV array, inverter, and induction motor with associated control technique.

For Induction Motor the equations are given below. Using Kirchoff's law, the voltage equations for each winding on the stator and rotor can be determined.

$v=R i+d \Phi / d t$

The voltage equation for stator windings:

$\left[v_{s}\right]=\left[R_{s}\right]\left[i_{s}\right]+d\left[\Phi_{s}\right] / d t$

And rotor windings:

$\left[v_{r}\right]=[]\left[i_{r}\right]+d[\Phi] / d t$

and

$\left[v_{s \mathrm{~d}}\right]=\left[R_{s}\right]\left[i_{s \mathrm{~d}}\right]+d\left[\Phi_{s \mathrm{~d}}\right] / d t-\left[\omega_{\mathrm{s}}\right] \Phi_{s \mathrm{q}}$

$\left[v_{s q}\right]=\left[R_{s}\right]\left[i_{s q}\right]+d\left[\Phi_{s q}\right] / d t+\left[\omega_{s}\right] \Phi_{s \mathrm{~d}}$

$\left[v_{\mathrm{rd}}\right]=\left[R_{\mathrm{r}}\right]\left[i_{\mathrm{rd}}\right]+d\left[\Phi_{\mathrm{rd}}\right] / d t-\left[\omega_{\mathrm{r}}\right] \Phi_{\mathrm{rq}}$

$\left[v_{\mathrm{rq}}\right]=\left[R_{\mathrm{r}}\right]\left[i_{\mathrm{rq}}\right]+d\left[\Phi_{\mathrm{rq}}\right] / d t+\left[\omega_{\mathrm{r}}\right] \Phi_{\mathrm{rd}}$

Where

$v_{s \mathrm{~d}}, i_{s \mathrm{~d}}$ are $\mathrm{d}$ axis stator voltage and stator current respectively

$v_{\text {rd }}, i_{\text {rd }}$ are $\mathrm{d}$ axis rotor voltage and rotor current respectively

$v_{s q}, i_{s q}$ are $\mathrm{q}$ axis stator voltage and stator current respectively

$v_{\text {rq }}, i_{\text {rq }}$ are $\mathrm{q}$ axis rotor voltage and rotor current respectively

The mechanical model of the induction motor drive system may be written in generalized form as:

$\mathrm{T}_{\mathrm{e}}=\mathrm{T}_{\mathrm{L}}+\mathrm{J} d \omega / d t$

where

$\mathrm{T}_{\mathrm{e}}$ is electromagnetic torque

$\mathrm{T}_{\mathrm{L}}$ is load torque

$\mathrm{J}$ is inertia

$d \omega / d t$ is rate of change of angular velocity with time.

\section{DESIGNING OF BOOST CONVERTER USING FUZZY LOGIC CONTROLLER :}

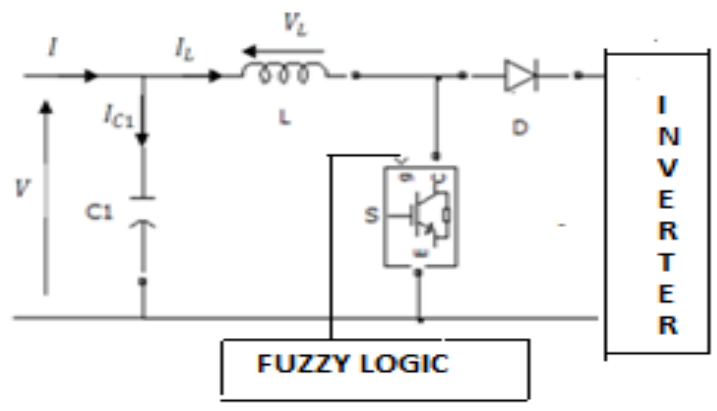

Fig.1 Circuit diagram of boost converter

Fig. 1 shows the implementation of fuzzy logic controller in boost converter in which value of inductor and capacitor are adjusted in order to give more output using different set of fuzzy rules as shown in Fig.2,3

$V^{*} T_{\text {ON }}=T_{\text {OFF }}\left(V_{0}-V\right)$

Dividing both sides by $\mathrm{T}$ and rearranging items gives

$V / V_{0}=T / t_{\text {off }}=1 / 1-D$
Then: $V_{0}=(1 / 1-D) V$

Where:

$\mathrm{T}$ is switching period and $\mathrm{D}$ is duty cycle.

$\mathrm{V}$ is voltage across capacitor which is basically output voltage of the solar PV Array.

$I=\left(K_{p 1}+\frac{K_{i 1}}{s}+s K_{s 1}\right) V$

$I$ is the measured current and it is compared with reference value which gives error

$E=I-I^{*}$

$\Delta E=E(t)-E(t-1)$

Rate of change of error is given by $\frac{d(\Delta E)}{d t}$

$\Delta E$ and $\frac{d(\Delta E)}{d t}$ are the inputs to the fuzzy logic controller

And the output corresponding is firing angle.

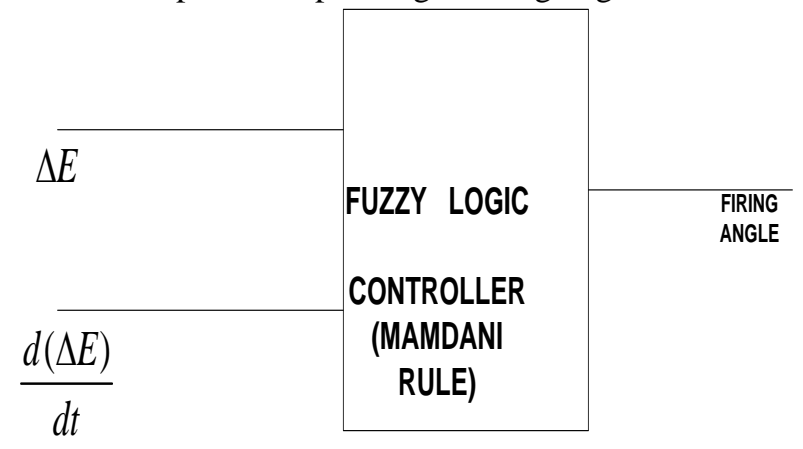

Fig. 2 Fuzzy model for boost converter

Fig. $3 \&$ Table. 1 shows the selection of input commands to the fuzzy logic controller as per the specification of the machine parameters

\begin{tabular}{|l|l|l|l|l|l|l|l|}
\hline $\begin{array}{l}\Delta E(\Delta E) \\
\frac{d(t}{|c|}\end{array}$ & NB & NM & NS & HB & HM & HS & HL \\
\hline NB & NS & NM & HL & HB & NM & NB & HB \\
\hline NM & HL & HB & NM & HL & HM & NM & HL \\
\hline NS & NB & NM & NS & HB & HM & HS & HL \\
\hline HB & NM & HL & HM & HS & NS & HM & NM \\
\hline HM & HM & NB & HL & NS & NB & NM & NS \\
\hline HS & NM & NM & NS & HB & HM & HS & HS \\
\hline HL & HS & HL & NB & HL & NM & NB & HL \\
\hline
\end{tabular}

Fig.3 Fuzzy Rules for boost converter

Fuzzy rules are decided by theory, Let $\mathrm{X}$ be classical crisp set of objects called universe, whose elements is given by $\mathrm{x}$. Membership function in subset $\mathrm{A}$ of $\mathrm{X}$ can realized as characteristic function $\mu_{A}$ from $\mathrm{X} \varepsilon[0,1]$

Published By: 
$\mu_{A}(x)=\{1, x=A$, otherwise, $x=0$

Set $[0,1]$ is validation set while Set A is fuzzy set, fuzzy set A is characterized by set of pair

$A=\left\{x, \mu_{A}(x)\right)$

$\mu_{A}(x)$ is called membership function of $\mathrm{x}$ in $\mathrm{A}$

In the same way we can defined for subset $B$

Where $\mu_{B}(x)$ is membership function of $\mathrm{x}$ in $\mathrm{B}$

$$
\mu_{A \cup B}(x)=\mu_{A}(x) * \mu_{B}(x)=\max \left[\mu_{A}(x) * \mu_{B}(x)\right]
$$

Table.1 Fuzzy rule selection

\begin{tabular}{|l|l|}
\hline Range of $\triangle E$ & Fuzzy selection \\
\hline $0<\triangle E<3$ & NB \\
\hline $3<\triangle E<6$ & NM \\
\hline $6<\triangle E<10$ & NS \\
\hline $10<\triangle E<14$ & HB \\
\hline $14<\triangle E<17$ & HM \\
\hline $17<\triangle E<19$ & HS \\
\hline $19<\triangle E<21$ & HL \\
\hline
\end{tabular}

\section{DESIGNING OF INVERTER USING FUZZY}

\section{LOGIC:}

Fig.5 shows the switching of boost converter and inverter using fuzzy logic. From the equation. 8 the output of induction motor drive is speed $\&$ torque $(w, T)$ ( which is passing to the PID controller

$$
\begin{aligned}
& e_{1}=w-w^{*} \\
& e_{2}=T-T^{*}
\end{aligned}
$$

The error $e_{1} \& e_{2}$ passed through PID controller gives modifies error $e_{3} \& e_{4}$

$$
\begin{aligned}
& e_{3}=\left(K_{p 2}+\frac{K_{i 2}}{s}+s K_{s 2}\right) e_{1} \\
& e_{4}=\left(K_{p 3}+\frac{K_{i 3}}{s}+s K_{s 3}\right) e_{2}
\end{aligned}
$$

Final Error produced here which is input to fuzzy logic controller is given by

$$
E=e_{3}-e_{4}
$$

Change in error is given by

$\Delta E=E(t)-E(t-1)$

$E_{\&} \Delta E$ and are inputs to fuzzy logic controller

And the output corresponding is firing angle

Selection criteria for selecting the fuzzy rules is same as of Eq.(15) \& (16).

Fig.4 shows the selection of fuzzy rules for inverter switching

\begin{tabular}{|l|l|l|l|l|l|l|l|}
\hline $\begin{array}{l}\Delta E / \\
E\end{array}$ & NB & NM & NS & HB & HM & HS & HL \\
\hline NB & NM & NS & HB & NS & HM & HL & HS \\
\hline NM & NB & HL & NB & NS & NM & HM & HL \\
\hline NS & HB & HM & NB & NM & NS & HS & HS \\
\hline HB & NS & HS & HL & HM & HS & NB & HM \\
\hline HM & HL & HB & NM & NS & HB & NM & NB \\
\hline HS & HM & NM & HB & HM & NS & NS & NM \\
\hline HL & HS & NM & NS & HB & HM & HS & NS \\
\hline
\end{tabular}

Fig.4 Fuzzy Rules for inverter

Table.2 .THD comparison:

\begin{tabular}{|c|c|}
\hline Fuzzy logic switching for & THD \\
\hline Boost converter output voltage & $5 \%$ \\
\hline Inverter output voltage & $3 \%$ \\
\hline DC link voltage & $15 \%$ \\
\hline
\end{tabular}

Fig. $6 \&$ Fig. 7 shows the performance of induction motor and inverter in terms of different parameters under no load condition and its analysis in terms of harmonics calculation as shown in Table. 2 and it was showing that THD for all the parameters are lying within range under the permissible range of $10 \%$

\section{CONCLUSION}

This paper shows the perfect application of fuzzy logic controller in solar PV Array system using boost converter and inverter feeding the induction motor drive. It is found that switching of boost converter by considering solar PV array parameters and switching of inverter by considering induction motor parameters combindly by using fuzzy logic controller using Mamdani rule makes the system to gives desired output. The Output parameter of Induction motor drive are controlled efficiently with minimum distortion less level. The complete system of solar PV array based induction motor drive gives reliable, efficient, lesser maintenance required, lesser THD value.

Table.3. Solar PV Parameters

\section{PARAMETER}

No. of cell per module

No. of series connected module per string

No. of Parallel string

Open circuit voltage(Voc)

Short circuit current(Isc)

Maximum Voltage(Vmp)

Maximum Current(Imp)

Series resistance(Rs)

Parallel resistance(Rp)

Saturation current(Isat)

Phase current(Iph)
VALUE

90

4

58

$74.2 \mathrm{~V}$

$9.82 \mathrm{~A}$

$64.8 \mathrm{~V}$

$6.42 \mathrm{~A}$

0.41

928.87

$2.67 * 10^{-6}$

$6.24 \mathrm{~A}$ 


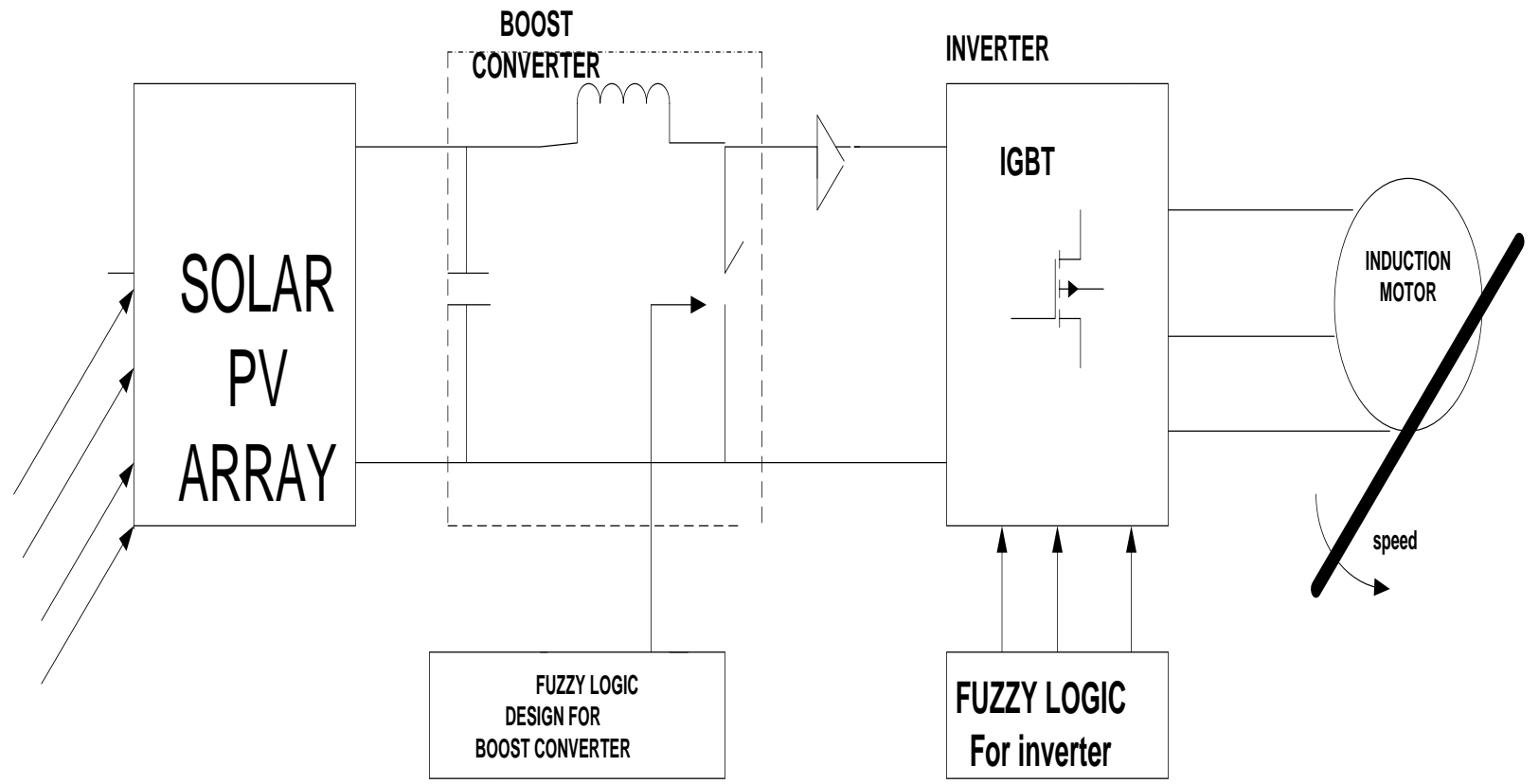

Fig.5. Block Diagram of the solar PV Array based system feeding induction motor using Fuzzy logic
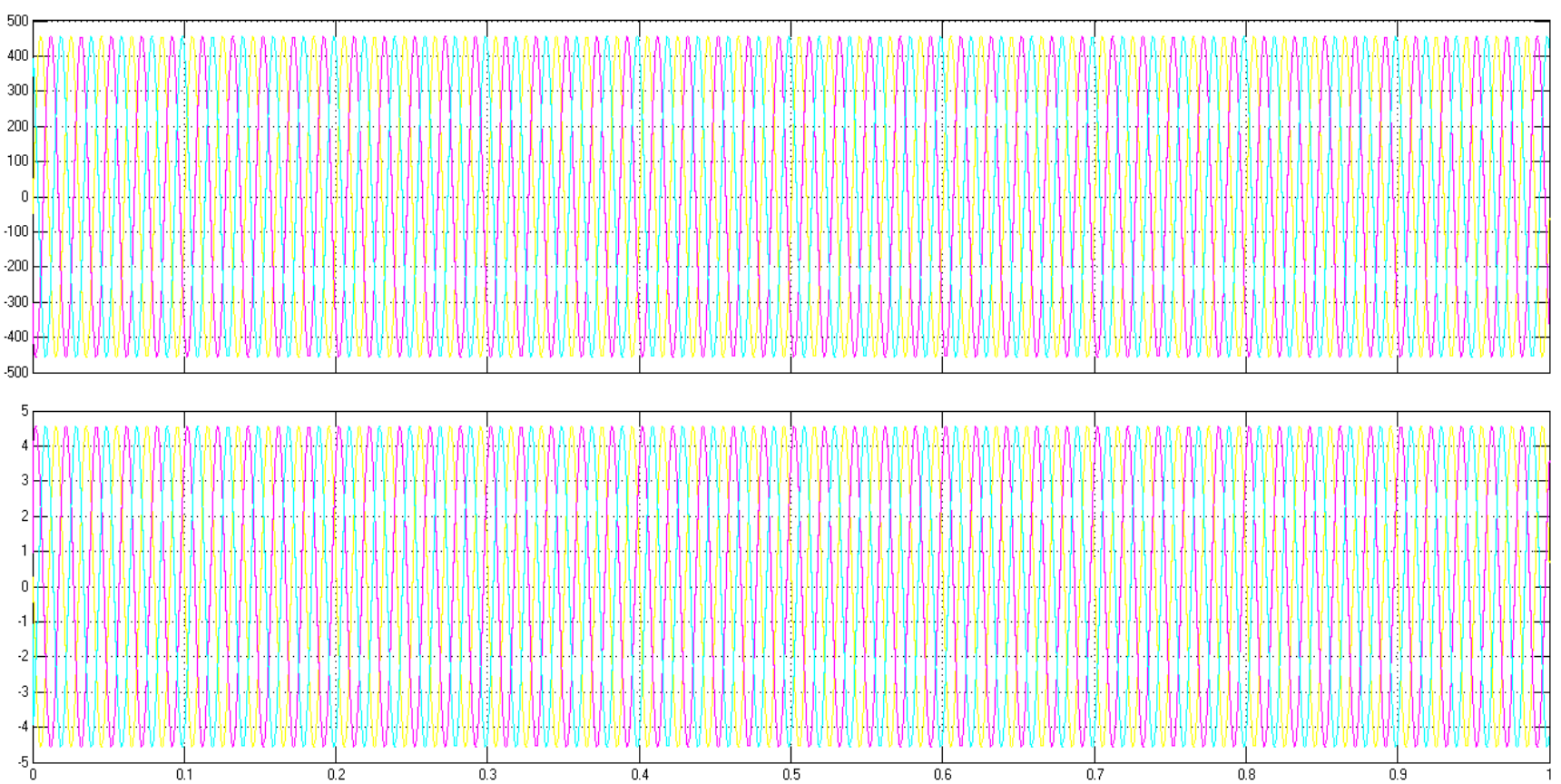

Fig.6 Output of inverter for driven the Induction motor 

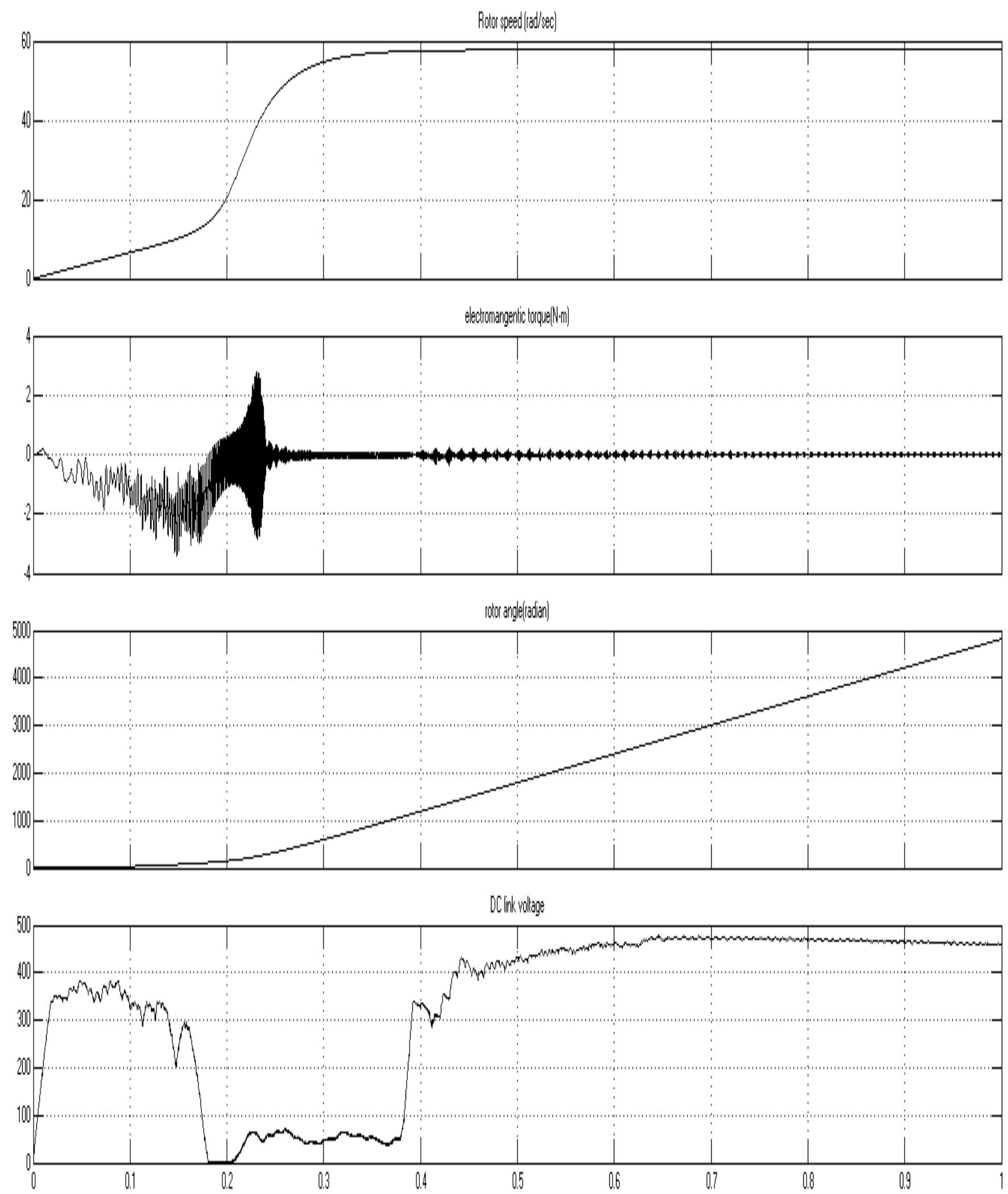

Fig.7 Performance characteristics of Induction motor drive with DC link 
Internal Parameters of Induction motor drive

$15 \mathrm{KW}, 415 \mathrm{~V}, 50 \mathrm{~Hz}, 6$ pole, $\mathrm{H}=0.385$

$\begin{array}{ll}\text { Parameters } & \text { Value } \\ \text { Stator Resistance(Rs) } & 0.01 \mathrm{pu} \\ \text { Stator Inductance(Ls) } & 0.28 \mathrm{pu} \\ \text { Rotor Resistance }(\mathrm{Rr}) & 0.032 \mathrm{pu} \\ \text { Rotor Inductance }(\mathrm{Lr}) & 0.18 \mathrm{pu} \\ \text { Mutual } & 0.20 \mathrm{pu}\end{array}$

Inductance $(\mathrm{Lm})$

\section{Appendix:}

$\mathrm{K}_{\mathrm{p} 1}=22.5, \mathrm{~K}_{\mathrm{i} 1}=49.8, \mathrm{~K}_{\mathrm{s} 1}=56.5$

$\mathrm{K}_{\mathrm{p} 2}=32.59, \mathrm{~K}_{\mathrm{i} 2}=55.98, \mathrm{~K}_{\mathrm{s} 2}=69.8$

$\mathrm{K}_{\mathrm{p} 3}=55.6, \mathrm{~K}_{\mathrm{i} 3}=87.59, \mathrm{~K}_{\mathrm{s} 3}=66.8$

\section{REFERENCES}

1. Saurabh Shukla and Bhim Singh,'Single Stage PV Array Fed Speed Sensorless Vector Control of Induction Motor Drive for Water Pumping',DOI 10.1109/TIA.2018.2810263, IEEE Transactions on Industry Applications, 2018

2. Manasa. M. Shetty, Girish Joshi, "Simulation of MPPT using Fuzzy Logic Controller for AC Drive" International journal of Innovative research in electrical, electronics, instrumentation and control engineering, Vol. 3, Special issue 1, April 2015.

3. Nurul Afiqah Zainal, Chan Sooi Tat and Ajisman "Fuzzy Logic Controlled Solar Module for Driving ThreePhase Induction Motor" IOP Conf. Series: Materials Science and Engineering 114 (2016).

4. Max Savio, Jayavelu "Drive Applications of Fuzzy Logic Controlled Interleaved Boost Converter for Maximum Power Point Tracking in Solar PV" 2016 IJEDR | Volume 4, Issue 4,2016.

5. M. A. Elgendy, D. J. Atkinson and B. Zahawi, "Experimental investigation of the incremental conductance maximum power point tracking algorithm at high perturbation rates," IET Renewable Power Generation, vol. 10, no. 2, pp. 133-139, Feb. 2016.

6. J. Titus, J. Teja, K. Hatua and K. Vasudevan, “An Improved Scheme for Extended Power Loss Ride-Through in a Voltage-Source-Inverter-Fed Vector-Controlled Induction Motor Drive Using a Loss Minimization Technique," IEEE Trans. Ind. Appl., vol. 52, no. 2, pp. 1500-1508, March-April 2016.

7. S. A. Odhano, R. Bojoi, A. Boglietti, S. G. Roşu and G. Griva, "Maximum Efficiency per Torque Direct Flux Vector Control of Induction Motor Drives," IEEE Trans. Ind. Appl., vol. 51, no. 6, pp. 4415-4424, Nov.-Dec. 2015.

8. L. An and D. D. C. Lu, "Design of a single-switch DC/DC converter for a PV-battery-powered pump system with PFM+PWM control," in IEEE Trans. Ind. Electron., vol. 62, no. 2, pp. 910-921, Feb. 2015.

9. D. Stojić, M. Milinković, S. Veinović and I. Klasnić, "Improved stator flux estimator for speed sensorless induction motor drives," IEEE Trans. Power Electron., vol. 30, no. 4, pp. 2363-2371, April 2015.

10. A. B. Raju, S. Kanik and R. Jyoti, "Maximum efficiency operation of a single stage inverter fed induction motor PV water pumping system", Emerging Trends in Eng. And Tech. (ICETET), pp.905-910, 2008.

11. C. Jain and B. Singh, "Single-phase single-stage multifunctional grid interfaced solar photo-voltaic system under abnormal grid conditions", IET Genr., Trans. \& Distr., vol. 9, no. 10, pp. 886-894, Feb.2015.

12. Bhavnesh Kumar, Yogesh K. Chauhan, and Vivek Shrivastava "Solar Powered Fuzzy Logic Controller based Vector Controlled Induction Motor Drive" Journal of Automation and Control Engineering Vol. 1, No. 4, December 2013

13. Abubakkar Siddik. A, Shangeetha. M "Implementation of Fuzzy Logic controller in Photovoltaic Power generation using Boost Converter and Boost Inverter" International Journal of Power Electronics and Drive System (IJPEDS) Vol. 2, No. 3, September 2012, pp. 249 256.

14. Satean Tunyasrirut, Tianchai Suksri, and Sompong Srilad "Fuzzy Logic Control for a Speed Control of Induction Motor using Space Vector Pulse Width Modulation ."World Academy of Science, Engineering and Technology International Journal of Computer and Information Engineering Vol:1, No:1, 2007

15. V. Chitra, and R. S. Prabhakar "Induction Motor Speed Control using Fuzzy Logic Controller." World Academy of Science, Engineering and Technology 23, pp. 756-761, 2008.

\section{AUTHORS PROFILE}

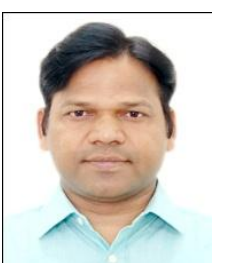

Dr. Arunesh Kumar Singh graduated in Electrical Engineering and M.Tech. in Engineering Systems from Faculty of Engineering, Dayalbagh Educational Institute (Deemed University), Dayalbagh, Agra in 2002 and 2004 respectively. He has been awarded Ph.D. in Electrical Engineeringfrom Jamia Millia Islamia (A Central University), New Delhi in 2011. He has been awarded Postdoctoral Fellowship (PDF) for 17 months (w.e.f. August, 2016) from University of Saskatchewan under Discovery Grant-NSERC, Canada to do research in the field of Neuro-Control Systems at Intelligent Systems Research Lab., College of Engineering, University of Saskatchewan, Saskatoon, Canada. He has successfully completed three certificate courses i.e. Laboratory Safety, WHMIS (Workplace Hazardous Materials Information System) and Safety Orientation for Employee from University of Saskatchewan, Canada in 2016. He has also completed the Graduate in Professional Skills; Professional Skills Course: GPS-974 and Thinking Critically (Professional Skills for Global Citizens): GPS-984 from Gwenna Moss Centre for Teaching \& Learning, University of Saskatchewan, Canada in 2017 and awarded the Graduate certificate in May, 2018. He has worked as Jr. Telecom Officer (Executive) in B.S.N.L. since 2009 to 2011 and then joined the Department of Electrical Engineering, Jamia Millia Islamia, New Delhi as Assistant Professor since February, 2011. He has more than 14 years experience in teaching \& industry and he is actively involved in guiding the research scholars at UG, PG $\&$ Ph.D. level. He has completed a research project sponsored by UGC and also got a project from SERB. He has received a Best Paper Award for a paper in an IEEE sponsored international conference RDCAPE-2015 at Amity University, Noida. Now, he is Life Member of System Society of India (SSI) and Senior Member of IEEE. He is the recipient of BHARAT VIKAS AWARD-2018 for outstanding performance in the field of Electrical Machines \& Neuro-control by ISR, Bhubaneswar. His research area is intelligent systems, soft \& quantum computing, Neuro-control systems, Eddy current control systems, Neuro \& machine controls, Renewable energy system.He has published various research papers in refereed journals \& conferences of national and international repute.

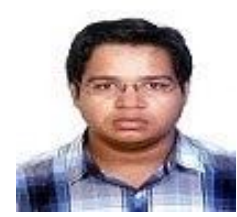

energy
Abhinav Saxena received the B.Tech.Degree in Electrical Engineering from U.P.T.U Lucknow in 2011 and M.Tech.from IIT Roorkee in 2013.Currently he is pursuing Ph.D. in Electrical Engineering from Jamia Millia Islamia, India. His research areas include Power Electronics, Electrical Machines, Power System, Control System and Intelligent Techniques, Renewable 